\title{
Impact of Improved Soybean Variety on Enhancing Productivity and Gross Farm Income of Smallholder Farmers in North Western Ethiopia
}

\author{
Welay Tesfay Desalegn Teshale \\ Ethiopia Institute of Agriculture Research, Pawe Agricultural Research Center Pawe, Ethiopia
}

\begin{abstract}
Adoption of improved nutrient rich industrial crops have an impact on increasing agricultural productivity, enhancing farm income, improving the nutrition and food security status of smallholder farmer in Ethiopia. The main objective of this study was to determine factors affecting the adoption of improved soybean varieties and to measure its impact on increasing soybean productivity as well as farm income of smallholder farmers in Ethiopia. The study applied logit regression model and propensity score matching methods (PSM) to determine the factors affecting adoption of improved soybean Variety and to measure its impact on the productivity and farm income enhancement at smallholder farmers' level. Total 167 soybean producers (100 were local soybean producer and 67 were improved soybean producers) were taken using systematic and random sampling methods. The result of logit regression showed that member of any community leadership, training on soybean production; know peoples who planted improved soybean variety and main source of information about the production and marketing of soybean were the main factors determining adoption of improved soybean variety in the study area. The PSM result revealed that adoption of improved soybean variety showed statistically significance and positive effect on the increasing of productivity and farm income of improved soybean variety beneficiary which brought $5 \%$ and $15 \%$ of increment in income and soybean productivity over the controlled groups respectively. This research suggests that adoptions of improved agricultural technologies are a means of poverty reduction as well as ensuring economic welfare of smallholder farmers. Therefore, governmental authorities, NGOs, policy maker and planners should be focused on the expanding and addressing of these improved agricultural technologies over all the countries.
\end{abstract}

Keywords: Adoption, impact, improved soybean variety, Income, productivity, PSM

DOI: $10.7176 / \mathrm{JNSR} / 9-15-04$

Publication date: August $31^{\text {st }} 2019$

\section{Introduction}

In Ethiopia, agriculture is the backbone of the economy that provides $85 \%$ of employment opportunity for active labor force, contributes more than $45 \%$ of GDP and $90 \%$ foreign currency earning. About $82 \%$ of the Ethiopian population are living in rural areas and engaged on farming for their livelihood(WorldBank, 2014). Agriculture serves as main source of staple foods for domestic consumption, and raw materials for domestic agro industries like food/feed factory, brewery factory and oil factories. Despite its importance, the sector has faced a number of bottlenecks to enhance its contribution to the national economy. Limited use of agricultural technologies, recurrent drought, limited use of mechanized agriculture, limited use of modern irrigation agriculture, subsistence small holder agriculture, rain fed agriculture and lack of appropriate land use systems are among the major bottlenecks (ATA, 2014).

Due to these bottlenecks, the Ethiopian rural smallholder farmers are investing low capital on agriculture and gained low return from it(source). As result the food security and poverty reduction in rural Ethiopian is still unanswered development agenda. In addition to this, malnutrition of infants under 5 five years was severe in Ethiopia due to poor habit and low capacity of feeding their families with nutrient rich, body building and disease preventing vegetables, fruits and animal products (Diro et al., 2017). Considering these facts, Ethiopian Growth and Transformation II (GTP II) have emphasis to produce nutrient rich, high value of industrial crops as well as to commercialize smallholder farmers by creating market linkage with potential consumers and industries.

Soy bean (Glycine) is among the industrial legume crops growing in low to medium altitude that needs warm climate(Hagos and Bekele, 2018). Unlike other beans it contains $40 \%$ of protein compare to $20 \%$ and $13 \%$ protein content in meat and egg respectively (Greenberg and Hartung, 1998). Moreover it is the highest in gross output of vegetative oil and primary source of edible oil among the cultivated crops with total cultivated area of 117.7 Million and total area of 308.4 million tons (FAOSTAT, 2015). Soy bean has multipurpose that used for human food, animal feeds, soil nutrient improvement and raw material for agro-industries. Production of this crop is vital in Ethiopia to overcome food insecurity and malnutrition and can substitute the relative expensive of animal protein. Potentially, it grows in Benshangule Gumuz, Oromia, Amhara, Tigray and South Nation and Nationalities people and become the main of source of income for smallholder farmers(Bekabil, 2015).

Soy bean was introduced to Ethiopia in the early of 1950s and becomes one of the most vital low land crops 
and adapted to low to medium agro ecology predominantly produced by smallholder farmers(Hagos and Bekele, 2018). The records from 2008 to 2018 indicated that soybean production has shown an increasing trend in terms of production and area which reached 864,678.69 qt, 38,072.70ha of cultivated land with average national productivity of $22.71 \mathrm{qt} / \mathrm{ha}(\mathrm{CSA}, 2018)$. This increment is due to emphasis of policy courage given to produce industrial and high value crops by smallholder farmers in GTP II.

Soybean was introduced lately in Benshangul gumuze and Amahara regions during the resettlement program in 1986. However, it is dominantly produced by smallholder farmers in Metekel and Awi zones of Benshangul Gumuz and Amhara regional states respectively and it becomes the main source of income and base of their livelihood to smallholder soybean producers (CSA, 2018).

Despite the importance of soybean to address the problem of food and nutrition insecurity in the country, little is known about the main determinants of improved soybean varieties adoption factors to promote soybean production, to meet the GTP plan II in 2020 and to supply the required soybean raw material to domestic factories. In addition to this, the impacts occurred due to the adoption of improved soybean varieties on increasing soybean productivity and gross farm income of beneficiaries' was not measured and evaluated.

There are limited empirical studies conducted related to adoption and impacts of improved soybean varieties. Moreover, its scope is limited within one district. (Zemedu et al., 2017) has conducted adoption and impact of improved soybean (Belesa-95) variety among smallholder farmer in Bambasi distict, Benshangul Gumuz region. The paper result showed that sex of household head, cooperative membership, oxen ownership, participation on training and demonstration was the determinant of improved soybean adoption. This paper indicated that improved soybean variety beneficiaries were earned birr 1118.1 amount of income greater than non-adopters. (Miruts, 2016) has conducted Analysis of the Factors Affecting Adoption of Soybean Production Technology in Pawe District, Metekele Zone of Benshangul Gumuz Regional State, Ethiopia. The result identified that land holding, family size, number of livestock owned, extension contact was the determinant of improved soybean technology. (Diro et al., 2017) has also conducted Factors affecting adoption and degree of adoption of soybean in Ilu-Ababora Zone; Southwestern Ethiopia. The result of paper revealed that training on soybean production, education of the household head and access to extension service, farm size, age of the household head and distance to the market was the determinant of improved soybean technology adoption.

However, almost all these empirical researches were focused on determinant of adoption as well as limited in area of coverages. This research is wider in area coverage as well as research contents that conducted in Northern western Ethiopia that covers two regions (Amhara and Benshangul Gumuz) and it contains both adoption and impact of improved soybean technology. Therefore, it is essential to determine the factors affecting the adoption of improved soybean technology and to measure its impact on smallholders' soybean productivity and increasing their total farm income. The result of the paper is important to boost the soybean production at national level and to substitute the import of soybean for domestic oil and food factories. It is also important to targeted agricultural extension activities, evidence based decision and policy options for increasing income and soybean productivity of smallholder farmers. This paper is intended then to fill the knowledge gap of determinant of improved soybean technology and its impact on increasing of total income and soybean productivity of the smallholder farmers.

Therefore, this research has focused on factors determining improved soybean varieties adoption and its potential impact of gross farm income and soybean productivity in north western Ethiopia.

\section{Research Methodology}

\subsection{Description of the study area}

The study is conducted in Pawe district, Metekel zone Benshangul Gumuz region and in Jawi district, Awi zone Amhara region, North Western Ethiopia. Pawe is found at $567 \mathrm{Km}$ to North West direction far away from Addis Ababa with geographical location at 36 $27^{\prime} 21.88^{\prime}$ '- $36^{0} 28^{\prime} 22.95^{\prime}$ ' longitude and latitude of $11^{0} 20^{\prime} 04.93$ '. $11^{0} 17^{\prime} 50.43^{\prime \prime}$. It covers an area of 63,400 hectare with estimate population of $59,127(50.76 \%$ male) inhabitants (PDAO, 2018). The farming system of the district is characterized as mixed crop-livestock farming system dominated by cereal and pulses crops. Among the pulses, soybean takes a lion share in terms of production and area coverage (CSA, 2018). The district is bounded in East and North by Jawi district, in South by Mandura district, in West by Dangur districts. It is characterized as warm humid low land area with high rain fall. The district has 20 kebeles and the climate of the area is hot humid and characterized by unimodal rainfall pattern with high and heavy rainfall that exceeds from May to October. The area receives mean annual rainfall of $1586.32 \mathrm{~mm}$ and it has an altitude of $1120 \mathrm{~m}$ with mean annual temperature of $16^{\circ} \mathrm{c}$ to $32^{\circ} \mathrm{c}$ which ranges $12^{\circ} \mathrm{c}$ to $40{ }^{\circ} \mathrm{c}$ (Miruts, 2016).

Jawi district is found at $602 \mathrm{Km}$ to North West direction far away from Addis Ababa with geographical location at $36^{0} 29^{\prime} 17.58^{\prime}$ ' longitude and latitude of $11^{0} 33^{\prime} 22.68^{\prime}$ '. It covers an area of 515,400 hectare with estimate population of $122,259(53.08 \%$ male) inhabitants (JDAO, 2018). The farming system of the district is characterized as mixed crop-livestock farming system dominated by cereal and pulses crops. Among the pulses, soybean takes a lion share in terms of production and area coverage (CSA, 2018). Jawi district is bounded in East by Dangla district, in South by Dangur and pawe district, in West by Quara districts and in North by Alefa Taqusa district. It 
is characterized as warm humid low land area with high rain fall. The district has 25 kebeles and the climate of the area is hot humid and characterized by unimodal rainfall pattern with high and heavy rainfall that exceeds from May to October. The area receives mean annual rainfall of $1250 \mathrm{~mm}$ and its altitude ranges from 700 to 1500 m.a.s.1 with mean annual temperature of $16^{\circ} \mathrm{c}$ to $320 \mathrm{c}$ which ranges $12^{\circ} \mathrm{c}$ to $40^{\circ} \mathrm{c}$ Jawi district agricultural office (JDAO, 2018).

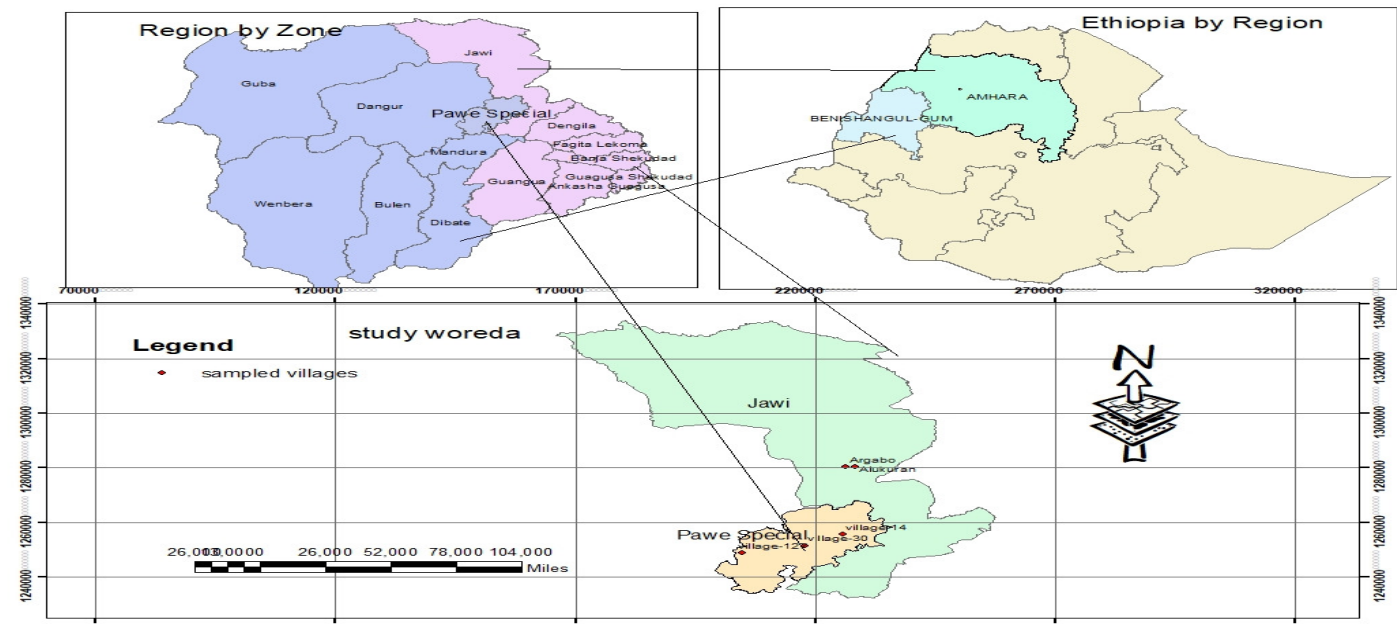

Fig $_{1}$ Map of Study Areas

\subsection{Sampling method and sample size determination}

The study used multi stage probability sampling methods. Awi and Metekel zones are the major soybean producers in Amhara and Benshagul Gumuz region respectively in North Western of Ethiopia which were target population for this study. In the first stage of probability sampling methods, soybean producer districts were listed and selected one districts from each zone using simple random sampling methods. Based on this Pawe and Jawi districts were selected randomly from Metekel and Awi zones respectively. In the second stage of probability sampling method, soybean producer kebles were listed with consecutive serial number in each district and three and two kebles were selected from Pawe and Jawi respectively using simple random sampling methods. In the third stage smallholder soybean producers were listed in consecutive serial number in each randomly selected kebles. Finally, soybean producer smallholder farmers were selected using systematic sampling method and probability proportion to sample size.

The total sample size was taken based on the following formula(Cochran, 2007).

$n=Z^{2}(P Q) / e^{2}$

\section{$-1$}

Where

$\mathrm{n}$ - Is number of sample size , $\mathrm{Z}$ - Is $95 \%$ confidence limit i.e. 1.96

p - Is 0.3 (proportion of the population to be included in the sample i.e $30 \%$ )

$\mathrm{q}$ - Is 0.7 proportion of the population not to be included in the sample i.e $70 \%$ )

e - Is margin of error or degree of accuracy desired (0.05)

According this formula 167 sample households were taken from two districts. The sample distribution is illustrated as follow.

Table 1 Smallholder soybean producers by Districts and Kebles

\begin{tabular}{|c|c|c|c|}
\hline District & Keble & \# of sample unit selected & Share of sample in \% \\
\hline \multirow[t]{3}{*}{ Pawe } & 127 & 35 & 20.96 \\
\hline & 14 & 44 & 26.35 \\
\hline & 30 & 22 & 13.17 \\
\hline \multirow[t]{3}{*}{ Jawi } & Alukuran & 37 & 22.15 \\
\hline & Arigabo & 29 & 17.37 \\
\hline & & 167 & 100 \\
\hline
\end{tabular}

Source: Survey data (2018)

\subsection{Types and method of data collection}

The study used both primary and secondary data which collected through structured questionnaire and checklists respectively. Primary data were collected by trained enumerators from sample households of soybean producers through face to face interview whereas secondary data were collected from published and unpublished documented of zonal and district administrative offices. In addition to this, personal observation, focus group discussion and key informant interviews were conducted to support the interpretation of the result obtained from field survey. 


\subsection{Methods of data analysis}

\subsubsection{Descriptive Statistics}

Descriptive statistics like mean, standard deviation and frequency were widely employed to describe the socio economic and institutional characteristics of sample households in study area.

Table 2 Summary of covariate used in the study

\begin{tabular}{|c|c|c|}
\hline Variables & Measurement & Expected Sign \\
\hline Age & Continuous, years of old & + \\
\hline Farm experience & Continuous, years of farming & + \\
\hline Soybean Area & Continuous, land allocated in ha & + \\
\hline Labor force(ME) & Continuous, active labor force in $\mathrm{ME}$ & + \\
\hline $\operatorname{Seed}(\mathrm{Kg} / \mathrm{ha})$ & Continuous, amount of seed used in $\mathrm{Kg}$ & + \\
\hline Cost seed(birr/ha) & Continuous, cost of seed incurred/ha & - \\
\hline Family size & Continuous, number person live together & - \\
\hline Distance to district market & Continuous, measure in minute & - \\
\hline Model farmer & Dummy, Yes/No & + \\
\hline Education & Discrete $1-4^{\text {th }} \ldots 9-12^{\text {th }}$ & + \\
\hline Member of any community leadership & Dummy, Yes/No & + \\
\hline Access to Financial service & Dummy, Yes/No & + \\
\hline Training on soybean production & Dummy, Yes/No & + \\
\hline Extension contact with DA & Dummy, Yes/No & + \\
\hline Know people who used Improve soybean & Dummy, Yes/No & + \\
\hline $\begin{array}{c}\text { Main source of Information on production and } \\
\text { marketing of soybean }\end{array}$ & $\begin{array}{l}\text { Discrete, Gov't extension, cooperative, } \\
\text { neighbor, seed trader, relative, research } \\
\text { center, seed enterprise }\end{array}$ & + \\
\hline
\end{tabular}

\subsubsection{Propensity score matching (PSM)}

According to (Khandker, 2010) impact evaluation is the act of studying whether the changes in well-being are indeed due to the intervention or not. The main aim of Adoption and impact of improved soybean was to determine factors affecting improved soybean technology as well as to measure its impact on increasing of soybean productivity and total farm income of stallholders' farmers. To this effect, there is a need to see whether the intervention of adoption improved soybean variety has significant impact on the improved soybean variety producers' or not. However, to compare them with and without intervention difference, baseline survey was not conducted prior to the intervention of the adoption of improved soybean variety in the study area. Therefore, this study uses propensity score matching (PSM) method because PSM is the appropriate method when such kind of problem arises. Following (Caliendo and Kopeinig, 2008), there are some steps in implementing PSM. These are: PSM estimation, choosing matching algorithm, checking for overlap (common support), matching quality (effect) estimation and sensitivity analysis.

\subsubsection{Propensity score estimation procedure}

Propensity score estimation is the first step in PSM technique. When estimating the propensity score, two choices have to be made. The first one concerns the model to be used for the estimation, and the second one the variables to be included in this model. In principle any discrete choice model can be used. Preference for logit or probit models (compared to linear probability models) derives from the well-known shortcomings of the linear probability model, especially the unlike of the functional form when the response variable is highly skewed and predictions that are outside the $[0,1]$ bounds of probabilities. For the binary treatment case, where estimated the probability of participation versus non-participation, logit and probit models usually yield similar results (Caliendo and Kopeinig, 2008). For this study, logit model was used to estimate propensity score.

Regarding, the choice of variables (Smith and Todd, 2005) suggested that economic theory, a sound knowledge of previous research and also information about the institutional settings should guide the researcher in building up the model. However, concerning the inclusion (or exclusion) of covariates in the propensity score model. The matching strategy builds on the CIA, requiring that the outcome variable(s) must be independent of treatment conditional on the propensity score. Hence, implementing matching requires choosing a set of variables $\mathrm{X}$ that credibly satisfy this condition.

According to (Gujarati, 2009) in estimating the logit model, the dependent variable is adopter and nonadopters of improved soybean variety which takes a value of 1 if they produce improved soybean variety and it takes 0 if they were produced local/old soybean variety.

The mathematical formulation of logit model is as follows:

$$
P i=\frac{e^{Z i}}{1+e^{Z i}}-------7
$$


Where: $-\mathrm{Pi}=\mathrm{i}^{\text {th }}$ household probability of producing soybean variety, adopting improved soybean variety takes 1 whereas local soybean producers take 0

$Z i=\alpha+\beta X i+U i------8$

Where $\mathrm{I}=1,2,3 \ldots \mathrm{N}, \boldsymbol{\alpha}=$ Intercept

$\beta=$ regression coefficient to be estimated, $\mathrm{Xi}=$ Explanatory variables and $\mathrm{Ui}=$ Random error

The effect of household's adopting improved soybean variety on a given outcome(Y) is specified as $T i=$ $\mathrm{Yi}(\mathrm{D}=1)-\mathrm{Yi}(\mathrm{D}=0)-------9$

Where $\mathrm{Ti}=$ a treatment effect (effect due to adopting improved soybean variety),

$\mathrm{Yi}=$ is the outcome on the $\mathrm{i}^{\text {th }}$ household

$\mathrm{Di}=$ is whether the $\mathrm{i}^{\mathrm{Th}}$ household was adopted the improved variety or not

However Y ( $\mathrm{Di}=1)$ and $\mathrm{Yi}(\mathrm{Di}=0)$ cannot be observed for the same HHs simultaneously, estimating individual treatment effects $\mathrm{Ti}$ is impossible and one has to shift to estimating the average treatment effects of the population than the individual one. The most commonly used average treatment effect estimation is the average treatment effect on the treated $\left(\mathrm{T}_{\mathrm{ATT}}\right)$ which was $\mathrm{E}(\mathrm{T} / \mathrm{D}=1)=\mathrm{E}[\mathrm{Y}(1) / \mathrm{D}=1]-\mathrm{E}[\mathrm{Y}(0) / \mathrm{D}=1]$ specified as follow:

$T A T T=\mathrm{E}\left(\frac{\mathrm{T}}{\mathrm{D}}=1\right)=\mathrm{E}\left[\mathrm{Y} \frac{(1)}{D}=1\right]-\mathrm{E}\left[\mathrm{Y} \frac{(0)}{D}=1\right]----10$

Since the counter factual mean for those being treated, E (Y (0) / D = 1) is not observed, there is a need to choose a proper substitute for it to estimated ATT. Though it might be thought that using the mean outcome of untreated individuals' (y (0)) /D=0) as a substitute to the counter factual mean for these being treated, E (Y (0)/D=1) is possible, it is not a good idea especially in non-experimental studies. This is because it is likely that components which determine the treatment decision also determine the outcome variables of interest.

In our particular case, variable those determine HHs participation in the adopting of improved soybean variety affects HHs total gross farm income and soybean productivity. Therefore, the outcomes of individuals from adopter and non-adopter groups would differ even in the absence of treatment leading to a self-selection bias. However, by rearranging and subtracting $\mathrm{E}(\mathrm{y}(0) / \mathrm{D} 0)$ from both side of equation $6 \mathrm{~T}_{\mathrm{ATT}}$ can be specified as

$$
\begin{aligned}
E=\left[\mathrm{Y} \frac{(1)}{D}\right. & =1]-\mathrm{E}=\left[\mathrm{Y} \frac{(0)}{D}=0\right] \\
& =\mathrm{TATT}+\mathrm{E}\left[\mathrm{Y} \frac{(0)}{D}=1\right]-\mathrm{E}\left[\mathrm{Y} \frac{(0)}{D}=0\right]-----11
\end{aligned}
$$

In the above both terms in the left hand side are observables and ATT can be identified if no self-selection bias. That is if and only if E (y (0) however this condition can be ensured only in a randomize experiments (i.e. where there is no self-selection bias. Therefore, some identified assumptions must be introduced for non-experimental studies to solve the selection problems.

Basically there are two strong assumptions to selection problems those are

- Conditional independence assumption

- Common support condition

Conditional independence assumption

The CIA is given as $Y 0 Y 1 \quad D / X \quad X$-------------------------- 12

Where CIA ( indicates the outcome variable is independent of the explanatory variables which generated only due to the adoption of improved soybean varieties

$\mathrm{Xi}=\mathrm{a}$ set of observable characteristics

Yo $=$ Local/old soybean variety producers and Y1 $=$ Improved soybean variety producers

Given a set of observable covariates $(\mathrm{X})$ which is not affected the outcome variable. The impact of gross farm income as well as their soybean productivity enhancement was generated only due to the adoption of improved soybean variety.

\section{Results and Discussion}

The study was conducted in North Western Ethiopia particularly Pawe and Jawi districts. It examines the impact improved soybean varieties adoption on smallholder farmers' gross farm income and soybean productivity. It used descriptive statistics, Tobit, logit models and Propensity score matching method to analysis the data

\subsection{Descriptive Results}

Descriptive statistics were employed to describe the socio economic and institutional characteristics of sample households in study area. The descriptive results revealed that adopter households were statistically different from non-adopter groups in amount of seed used per hectare, cost of seed incurred per hectare, family size, being 
member of any community leadership, training on soybean production, social contact and source of information on production and marketing of soybean whereas the adopter groups did not make significance difference in terms of sex of household head, age ,farming experience, area allocated for soybean, active labor force, being model farmer, education, access to financial institution and extension contact with development agents (Table 3 and 4 ). The result is in line with (Afework et al., 2018), (Diro et al., 2017), (Zemedu et al., 2017).

\subsubsection{Demographic and socio economic characteristics of sampled households'}

Majority of the sample households were male head(91\%) and 9\% of them were female headed households. 35.93\% and $4.18 \%$ of the total sample households' were male and female household headed that adopted improved soybean variety respectively. The result of chi2 statistics revealed that sex of household has no difference on adopting of improved soybean variety. Majority of sample households' educational level were illiterate $(53.89 \%)$ and the rest of them were $1-12^{\text {th }}$ class complete $(46.11 \%)$. Among these $18.56 \%$ and $35.33 \%$ of them were adopter and nonadopters of illiterate sample households respectively. The chi2 statistics indicated that there is no educational level difference on adoption of improved soybean variety. Majority of sample households were not model farmers (68.26). 14.37\% and $17.37 \%$ of sample households responds from the adopter and non-adopter respectively as model farmer. The result revealed that being model farmer has no difference on adoption of improved variety. This is because improved soybean variety is disseminated and cultivated by most of smallholder farmers in study area in the last one and half decade.

Table 3 Summary of statistics for Demographic and Socio-economic variables

\begin{tabular}{|c|c|c|c|c|}
\hline $\begin{array}{c}\text { Demographic/socio economic } \\
\text { Variables }\end{array}$ & Adopter mean & $\begin{array}{l}\text { Non-adopter } \\
\text { mean }\end{array}$ & $\begin{array}{l}\text { Total sample } \\
\text { mean }\end{array}$ & $\begin{array}{l}\text { T-test or } X^{2} \\
\text { Value }\end{array}$ \\
\hline Sex & & & & 0.29 \\
\hline Male & 60 & 92 & 152 & \\
\hline Female & 7 & 8 & 15 & \\
\hline Family size & 5.05 & 5.82 & 5.51 & $2.25^{* *}$ \\
\hline Age & 43.72 & 42.09 & 43.72 & -0.92 \\
\hline Model farmer & & & & 0.86 \\
\hline Yes & 24 & 29 & 53 & \\
\hline No & 43 & 71 & 114 & \\
\hline Education & & & & 3.29 \\
\hline Illiterate & 31 & 59 & 90 & \\
\hline $1-4^{\text {th }}$ grade & 17 & 18 & 35 & \\
\hline $5-8^{\text {th }}$ grade & 16 & 18 & 34 & \\
\hline $9-12^{\text {th }}$ grade & 3 & 5 & 8 & \\
\hline
\end{tabular}

Source: Survey data (2018)

$*, * *, * * *$ Statistical Significance level at 1, 5 and $10 \%$ respectively

3.1.2 Social and Institutional characteristics of sampled households'

The institutional factors like contact with development agents, access to financial services have no statistically significance among adopters and non-adopters of improved soybean variety. The majority of sample households have been gained extension services during the study period $(86.76 \%$ ), which is $25.75 \%$ adopter and $61.01 \%$ nonadopter). Another factor was taken to investigate the adoption and impact of soybean variety in study area was access to financial institution. Only $37.72 \%$ of sample households 14.37 adopters and $23.35 \%$ non-adopters were access to financial service. This is due to limited of outreach of rural finance in study area. The chi 2 result showed that there is no statistical significance between adopter and non-adopters. This is due to poor saving habit as well as few amount money is saved in financial institution. This indicates that, even the saved money is not good enough to purchase improved agricultural technologies.

Social and institutional factors like member of any community leadership, training gained in soybean production, Social network and main source information on soybean production and marketing has positive effects on the adoption of improved soybean variety. $25.14 \%$ ( 13.77 adopter and 11.37 non-adopter), $46.46 \%$ ( 20.96 adopter and 25.50 non-adopter), $46.71 \%$ ( 31.14 adopter and 15.57non-adopter) 49.70\% (14.97 adopter and 34.73 non-adopter) of the total sample households were member of any community leadership, taking training on soybean production, social network and main source of information on soybean production and marketing was governmental extension program. Chi 2 results showed that member of community leadership, training on soybean production, social network and main source of information has positive difference and statistically significance at $5 \%, 10 \%, 1 \%$, and $1 \%$ respectively. It is obvious that being member of any community leadership help to distinguish the importance of improved technology. Gained capacity building on soybean production and social contact helped and encouraged to adopt improved soybean variety.

Other socio economic factors like farm experience, area allocated for soybean production, active labor force in Man equivalent was not showed statistically significance. Adopters of improved soybean varieties were expected older experienced in farming; allocated more land for soybean and has enough active labor force to 
manage their soybean farms. However, both the adopters and non-adopters were almost similar in these variables. That is why the T-test value result showed statistically insignificance. The amount of seed used and, incurred to purchase seeds and family size has positive effect on the adoption of improved soybean varieties. The T-test results showed that all of these variables were positive statistical significance difference at $5 \%$ to adopt improved soybean variety. This is because of adopters used near to the recommended seed rate than non-adopters as well as incurred lower cost of seed than non-adopter. The result is in line with (Miruts, 2016). The distance in minute to district market affects the soybean producers negatively. The T-test showed that negative statistical significance at $10 \%$ to adopt improved soybean variety. This indicated that as nearest market far away, they are less likely to adopt the improved soybean varieties. The result is in line with Diro et al (2017).

Table 4 Summary of statistics for Social and Institutional variables

\begin{tabular}{|c|c|c|c|c|}
\hline $\begin{array}{l}\text { Social and institutional } \\
\text { variables }\end{array}$ & Adopter mean & $\begin{array}{l}\text { Non-adopter } \\
\text { mean }\end{array}$ & $\begin{array}{l}\text { Total sample } \\
\text { mean }\end{array}$ & $X^{2}$ or T-test Value \\
\hline \multicolumn{4}{|c|}{ Member of any community leadership } & $5.01 * *$ \\
\hline Yes & 23 & 19 & 42 & \\
\hline No & 44 & 81 & 125 & \\
\hline \multicolumn{2}{|c|}{ Access to Financial service } & & & 0.17 \\
\hline Yes & 24 & 39 & 63 & \\
\hline No & 43 & 61 & 104 & \\
\hline \multicolumn{2}{|c|}{ Training on soybean production } & & & $1.69 *$ \\
\hline Yes & 35 & 42 & 77 & \\
\hline \multicolumn{2}{|c|}{ Extension contact with DA } & & & 0.26 \\
\hline Yes & 43 & 68 & 111 & \\
\hline No & 24 & 32 & 56 & \\
\hline \multicolumn{2}{|l|}{ Social network } & & & $42.93 * * *$ \\
\hline Yes & 52 & 26 & 78 & \\
\hline NO & 15 & 74 & & \\
\hline \multicolumn{4}{|c|}{ Main source of Information on production and marketing of soybean } & $26.12 * * *$ \\
\hline Government extension & 25 & 58 & & \\
\hline Cooperatives & 6 & 8 & & \\
\hline Neighbor farmer & 22 & 30 & & \\
\hline Research center & 14 & 3 & & \\
\hline Farm experience & 21.42 & 19.32 & 20.16 & -1.27 \\
\hline Soybean Area & 1.34 & 1.54 & 1.46 & 1.23 \\
\hline Labor force(ME) & 2.04 & 2.28 & 2.18 & 1.35 \\
\hline $\operatorname{Seed}(\mathrm{Kg} / \mathrm{ha})$ & 105.22 & 132.6 & 121.62 & $2.04 * *$ \\
\hline Cost seed(kg/ha) & 770.63 & 966.00 & 887.62 & $1.95 * *$ \\
\hline Distance to N Mkt' & 53.75 & 72.91 & 65.22 & $-1.68^{*}$ \\
\hline
\end{tabular}

Source: Survey data (2018)

$*, * *, * * *$ Statistical Significance level at 1,5 and $10 \%$ respectively

3.1.3 Adopter and non-adopter sampled households' by location

The study was conducted in Benshangul Gumuz and Amhara region and taken 167 soybean producers to examine the factor influencing adoption of improved soybean varieties as well as the gross farm income gained due to use of improved soybean variety over local soybean variety. Improved soy bean variety is more practiced in Benshangul(29.52\%) than Amhara region(10.84\%). 40.36\% of the sample household head were Adopter (use improved soybean variety) whereas the rest $59.64 \%$ were non adopters. The chi2 test showed that there is statistically significance between the two regions in the use of improved soybean varieties (Table 5). This is due to the high contact with researchers and Pawe district is nearest than Jawi district to the Pawe research center. Near distance to research area affects positively to adopt improved soybean variety.

Table 5 Adopter and non-adopter by region

\begin{tabular}{|c|c|c|c|c|c|c|c|c|}
\hline \multirow[t]{2}{*}{ Region } & \multicolumn{2}{|c|}{ Sex of HHs } & \multirow[t]{2}{*}{ Total } & \multirow[t]{2}{*}{$\%$} & \multicolumn{2}{|c|}{ Improved Soybean producers } & \multirow{2}{*}{$\begin{array}{c}\% \\
\text { Adopter }\end{array}$} & \multirow{2}{*}{$\begin{array}{l}\% \text { Non- } \\
\text { Adopter }\end{array}$} \\
\hline & Male & Female & & & Adopter & Non Adopter & & \\
\hline B/Gumuz & 86 & 15 & 101 & 60.48 & 49 & 52 & 48.52 & 51.48 \\
\hline Amhara & 66 & - & 66 & 39.52 & 18 & 48 & 27.27 & 72.73 \\
\hline Total & 152 & 15 & 167 & 100 & 67 & 100 & 40.11 & 59.89 \\
\hline
\end{tabular}

Source: Survey data (2018)

Improved soybean producers by region Pearson chi $2=7.50$ and $\operatorname{Pr}=0.006$

3.1.4 Soybean variety preference of sample households'

Most of sample households prefer Belesa 95 variety (59.28\%). Among these $25.15 \%$ were adopters and the rest 
$34.13 \%$ are non-adopters. $32.34 \%$ of the sample households prefer TGX variety. Among these $13.17 \%$ were adopters and $19.17 \%$ were non-adopters. However $8.38 \%$ of the sample households were not sure about the variety they sown. Among these $6.58 \%$ were non-adopters and $1.8 \%$ were adopters.

Table 6 Sample household head soybean variety use

\begin{tabular}{cccc} 
Sample HHs & Belesa 95 & TGX & Did not know \\
\hline Adopter & 42 & 22 & 3 \\
Non-Adopter & 57 & 32 & 11 \\
Total & 99 & 54 & 14
\end{tabular}

Source: Survey data (2018)

\subsubsection{Soybean marketing and Method of selling in the study area}

Soybean product was sold at farm gate, keble and district markets. $1.20 \%, 43.71 \%$ and $55.09 \%$ of the sampled households sold their soybean product in farm gate, district and keble market markets respectively. Most of sampled households were sold their soybean product in the keble market. 55.09 \% (26.95 adopter \& 28.14 non adopters) used this market place. Keble market is place located at the center of kebele which used as transaction place for the residences of kebeles'. Only $43.71 \%$ and 1.20 were used the district and farm gate market price place. Chi2 statics showed significance difference at 5\% between adopter and non-adopter in soybean selling place. Majority of sample households sold their soybean product after store for months. $25.75 \%, 22.75 \%, 51.50 \%$ of sample households sold their soybean production immediately after harvest, piece by piece and after stored respectively. Chi2 statistics showed there is no significance difference between the adopters and non-adopters in term of method of selling.

Table 7 Method of selling soybean production between Adopter and Non-adopters

\begin{tabular}{|c|c|c|c|c|}
\hline Method of selling soy & Adopter & Non Adopter & Total & $\mathrm{X}^{2}$ \\
\hline Immediately after harvest & 12 & 31 & 43 & \\
\hline Piece by piece & 18 & 20 & 38 & 3.80 \\
\hline After store & 37 & 49 & 86 & \\
\hline Place of sell & & & & \\
\hline Keble market & 45 & 47 & 92 & $6.95 * *$ \\
\hline District & 21 & 52 & 73 & \\
\hline Farm gate & 1 & 1 & 2 & \\
\hline
\end{tabular}

Source: Survey data (2018)

\subsection{Result of Econometrics Analysis}

\subsubsection{Identifying covariate variables contribute to outcome variable before intervention}

(Rosenbaum and Rubin, 1983) stated that Propensity score matching is the conditional probability of assignment to a particular treatment given vector of observed covariant. It used to control pre-intervention influence of covariates on the outcome variable that accomplished due to the intervention of improved technology. This study is try to examine the adoption and impact of improved soybean technology intervention on smallholder soy bean producers farm income and soybean productivity in North western of Ethiopia particularly Benshangul Gumuz and Amahara Regional states. Improved soybean variety producers considered as treated dependent variable where as local soybean producers considered as untreated or control dependent variables that takes 1 and 0 value respectively to easily identify the dependent variables.

Logistic regression model was applied to estimate propensity score matching of improved soybean and local soybean producers. VIF for continuous variables and contingent coefficient for dummy variables were calculated to detect the presence of strong multi-collinearity among covariant. To identify the adoption status of improved soybean producers in North Western Ethiopian seventeen covariates variables has been taken. Among these variables four of them affect the smallholder decision to participate on improved soybean variety adoption. These were People known who produced improved soy bean technology and Access to the information about the production, marketing and importance of improved technology was showed statistically highly significance at $1 \%$ and has positive effect whereas family size and distance to district market in minute was showed statically significance at $10 \%$ and has negative effect (Table 10). This is due to more family number per family decreases the marginal return of labor from a fixed amount of cultivated land. Even the income gained from that particular land cannot cover the family members' food and non-food consumption expenses. Family members who have large family size prefers to immigrate near to large farm lands in Mankush, Dangur and Quara districts and tried to gained additional income instead cultivated improved soybean variety in fragmented farmland within the family. The nearest to district market are more probability to adopt improved soybean variety. this is in line with (Diro et al., 2017).During estimation of impact pre intervention significance variable should be excluded from matching to control their contribution to outcome variables. Based on this, the significance covariates were excluded. 
Table 8 Identifying factors affecting adoption of improved soybean variety (Logistic Regression)

\begin{tabular}{|c|c|c|c|c|}
\hline Covariant & Coff & Std.Err & T-value & P-value \\
\hline Sex & 0.48 & 0.40 & 1.2 & 0.23 \\
\hline Age & 0.01 & 0.01 & 0.35 & 0.73 \\
\hline Farm experience & 0.01 & 0.01 & 0.95 & 0.34 \\
\hline Soybean Area & 0.17 & 0.18 & 0.96 & 0.34 \\
\hline Labor force(ME) & -0.04 & 0.13 & -0.28 & 0.78 \\
\hline Distance to district market in minute & -0.005 & 0.003 & $-1.75 *$ & 0.08 \\
\hline $\operatorname{seed}(\mathrm{kg} / \mathrm{ha})$ & -0.003 & 0.003 & -0.73 & 0.47 \\
\hline Cost seed $(\mathrm{kg} / \mathrm{ha})$ & -0.003 & 0.003 & -0.48 & 0.63 \\
\hline Education & 0.01 & 0.04 & 0.40 & 0.69 \\
\hline Model farmer & -0.06 & 0.27 & -0.23 & 0.82 \\
\hline Mem Leader & 0.46 & 0.28 & 1.61 & 0.11 \\
\hline Access to Financial Int & -0.23 & 0.25 & -0.92 & 0.36 \\
\hline Train on Soybean & 0.12 & 0.30 & 0.38 & 0.70 \\
\hline Extension Contact & 0.07 & 0.30 & 0.24 & 0.81 \\
\hline Know people who used improve soybean & 1.35 & 0.23 & $5.78 * * *$ & 0.000 \\
\hline Access to Soy Info & 0.14 & 0.05 & $2.81 * * *$ & 0.005 \\
\hline Family size & -0.11 & 0.06 & $-1.74 *$ & 0.082 \\
\hline cons & -0.87 & 0.82 & -1.06 & 0.29 \\
\hline
\end{tabular}

Source: Survey data (2018)

$*, * *, * * *$ Statistical Significance level at 1,5 and $10 \%$ respectively

\subsubsection{Estimate the propensity score matching and identifying the common support region}

The study was identifying thirteen statistically insignificance covariant to accomplish the matching processes. The significant variables should be excluded to identify the real impact of the improved soybean varieties otherwise the impact is not only the adoption of improved soybean varieties but also some significance explanatory variables. HenceThe statistically significance variables were excluded from further matching methods, estimating of propensity score and identifying of the common support region. Based on this the propensity scores of improved soybean producers distributed between 0.1681 and 0.8944 with a mean of 0.4795 whereas the local soybean producers propensity score distributed between 0.1743 and 0.7903 with a mean of 0.3459 (Table 9).

There are two approaches to map common support regions to match between the improved and local soybean producers. These are the minima and maxima and trimming approaches (Caliendo and Kopeinig, 2008). However, (Leuven and Sianesi, 2018) recommended using both approaches in combination at the same time and it gives good match in evaluation of impact using PSM. Therefore this study used both approaches in combination at the same time. Based on this criteria the common support region lies between 0.1681 and 0.7903 propensity score.

The sample household whose propensity scores out of this region is out of common support. According common support principle off support households' are discarded for matching process. As a result 22 sample households were discarded for further matching process.

Table 9 Distribution of estimated propensity scores

\begin{tabular}{|c|c|c|c|c|c|}
\hline Group & Obs & Mean & Std.dev & Min & Max \\
\hline Improved soybean producers & 67 & 0.4795 & 0.1642 & 0.1681 & 0.8944 \\
\hline Local soybean producer & 100 & 0.3459 & 0.1743 & 0.0424 & 0.7903 \\
\hline Sample HHs & Off Support & On support & Total & & \\
\hline Adopter & 2 & 65 & 67 & & \\
\hline Non-Adopter & 20 & 80 & 100 & & \\
\hline Total & 22 & 145 & 167 & & \\
\hline
\end{tabular}

Source: Survey data (2018)

\subsubsection{Propensity score distribution of the adopter and non-adopters}

The estimation of improved soybean variety adoption(propensity scores) for all participants and non-participants were accomplished from propensity of adoption. After identified the common support with and without the intervention, (in this case use of improved soybean variety and without use of improved soybean variety ), the off supports were discarded from the estimation process and at the last sensitivity analysis should be done to check the hidden biases affects the estimated ATT or not. As shown in figure 2 the kernel density distribution of propensity scores of the sample households is near to the normal distribution.Both of adopters and non adopters were found at the center and in the left side of the distrbution. Generally, figure 2 shows there is wide area of propensity score of treated groups simililar with the untreated or controlled groups of propensity score. It indicates there was considerable overlap(common support) in between the treated and untreated groups. Moreover, it dipted that there is high chance of getting good matches and large number of matched sample size from the distribution as both distribution concentrated at the center and skewed to the left. 


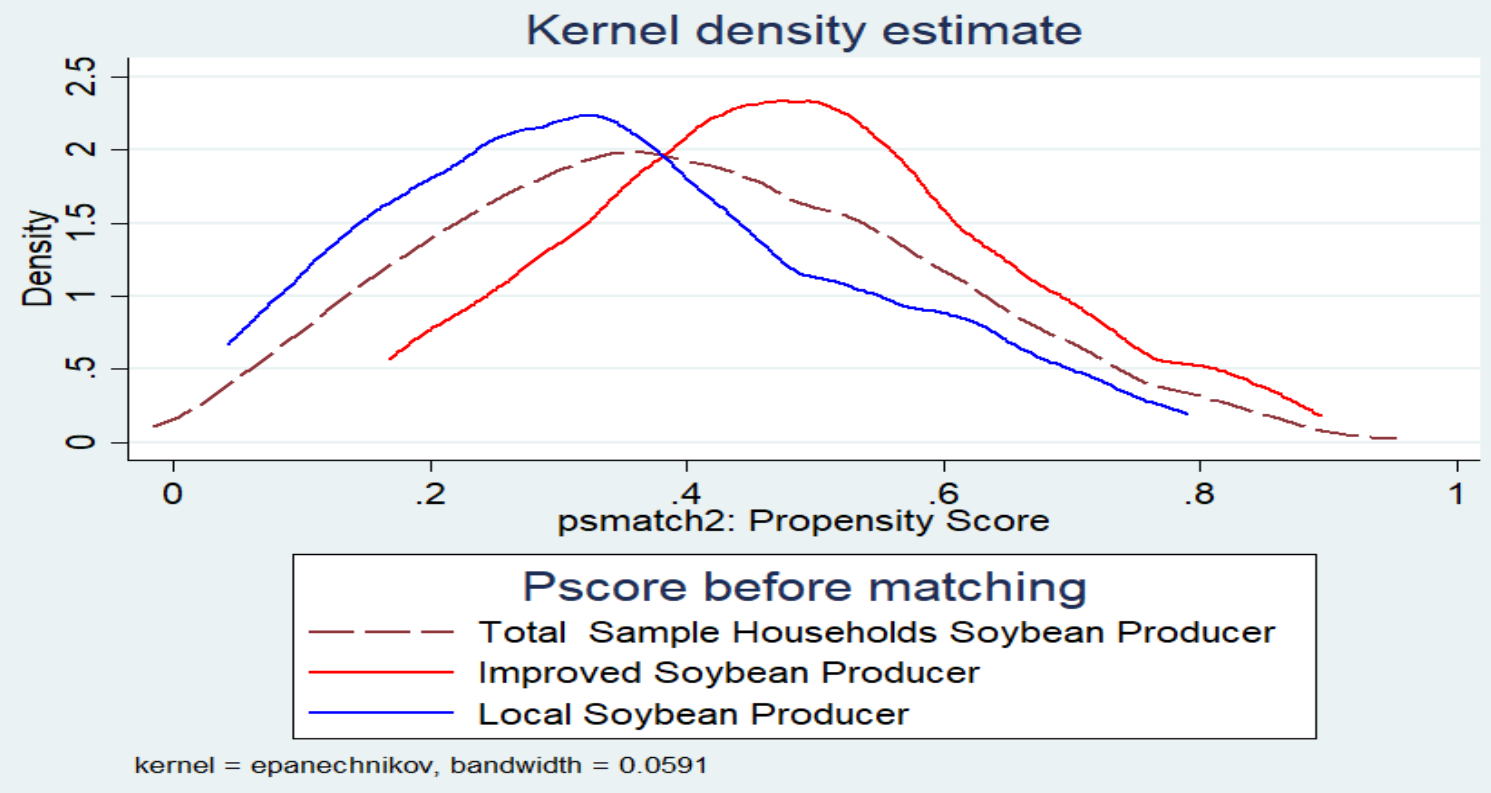

Figure 2 Total Sample Households Kernel density estimation of propensity score

\subsubsection{Matching of treated and controlled groups}

Matching of treated and untreated households was carried out to determine the common support region. The main criteria for determining the common support region is to discarded all observations whose propensity score is smaller than the minimum propensity score of adopters (treated) and larger than the maximum of the (controlled) non-adopters (Caliendo and Kopeinig, 2008). Based on this common support is satisfied in the region of (0.16810.7903 ) for sample households (Table 9). This means that households with estimated propensity scores less than 0.1681 and greater than 0.7903 are not considered in the matching undertaking. As a result 2 from treated and 20 untreated sample households) were discarded and 145 sample households were identified to be considered in the estimation process. The figure 3 portrays the distribution of estimated propensity scores, with and without the imposition of the common support condition for treated and untreated sample households respectively. The distribution of estimated propensity scores with the treated imposition of the common support condition, most of the treated households have propensity scores round 0.5 while majority of the untreated households have propensity score round 0.4 ( Fig 3, Fig 4).

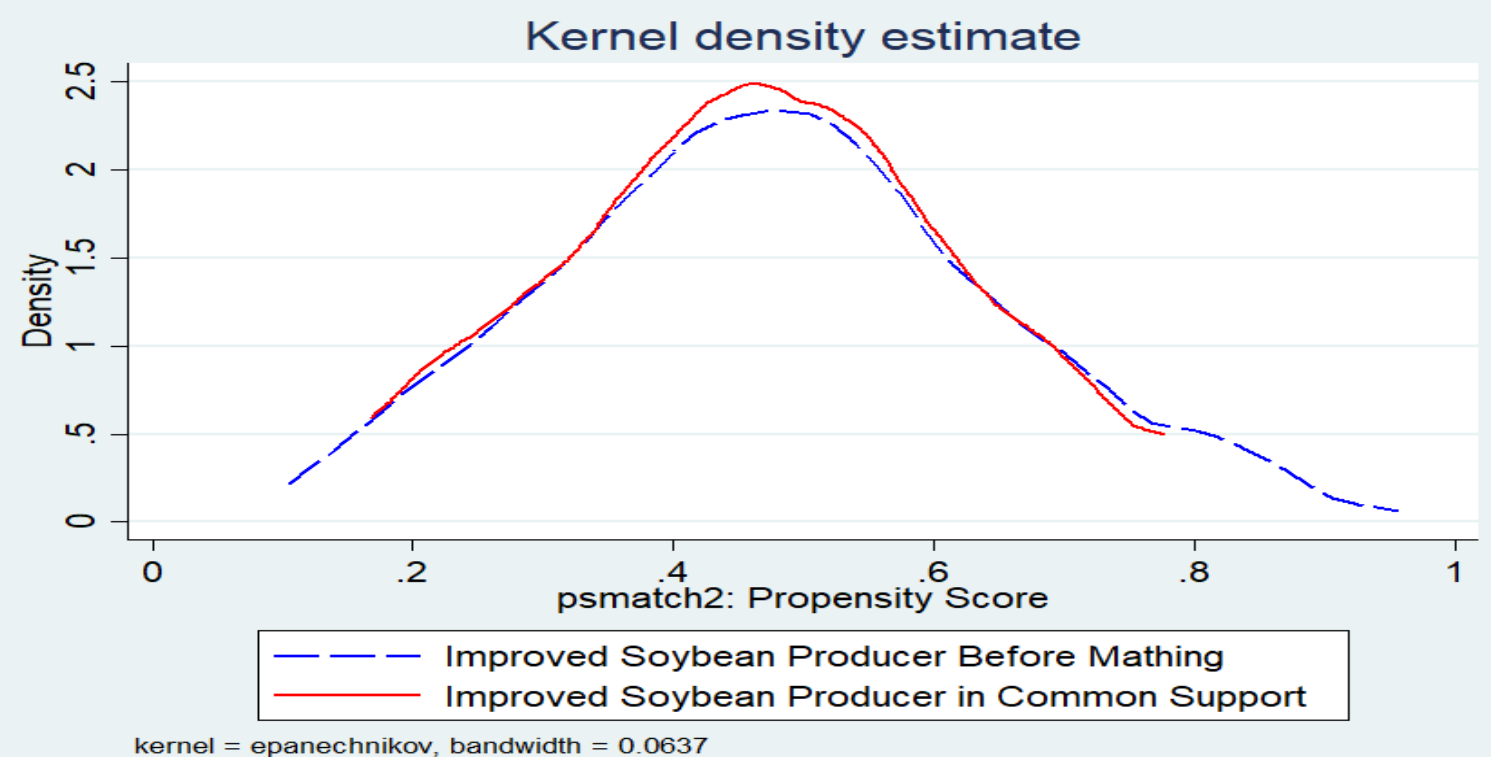

Figure 3 Kernel density estimate of propensity score of improved soybean producer with and without common support 


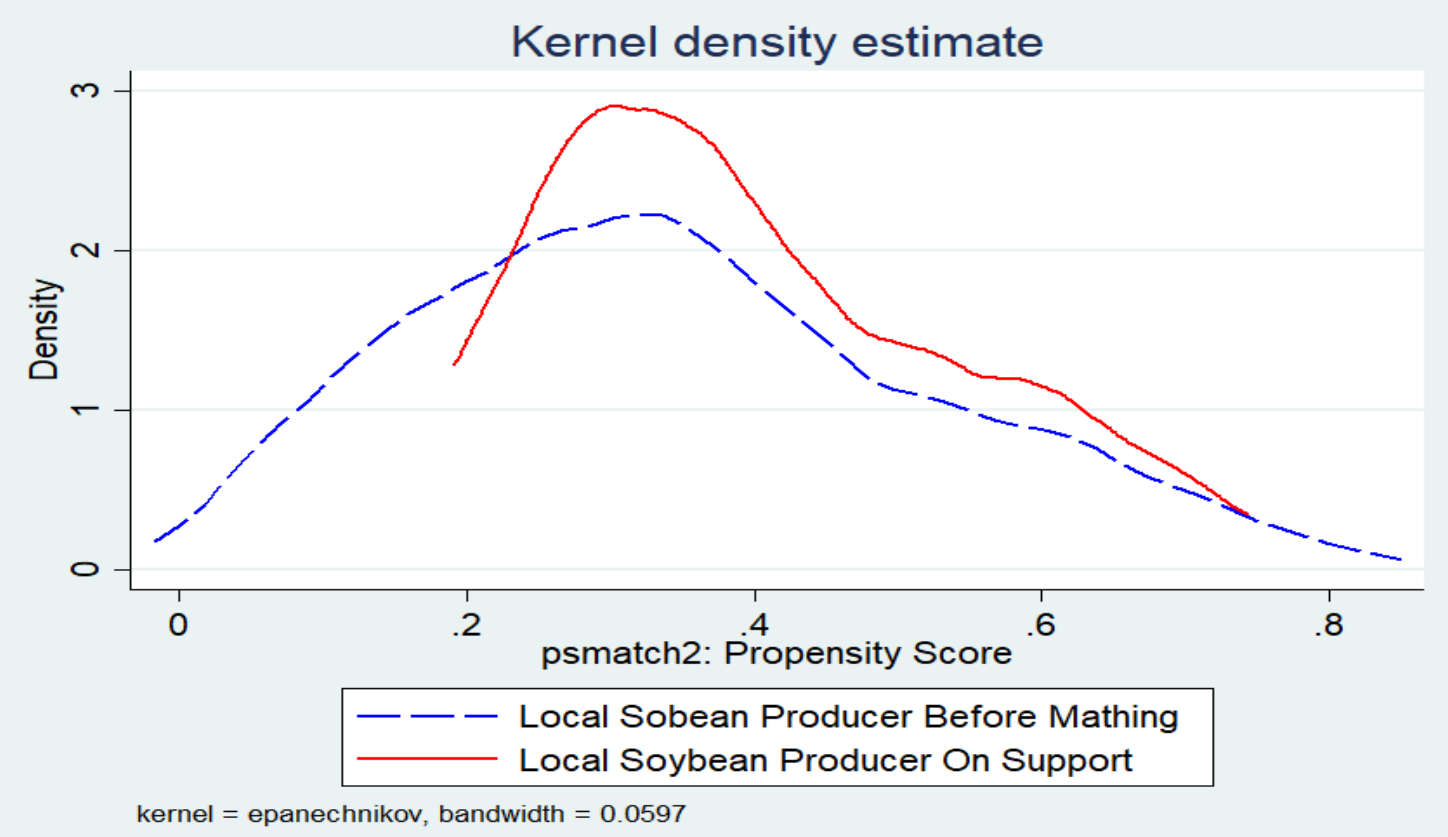

Figure 4. Kernel density estimation of propensity score of Local soybean producer with and without improved soybean Intervention

\subsubsection{Choice of matching algorism}

Matching algorism has three method of matching methods. The best algorism selected based on the three methods of matching, kernel bandwidth, and radius caliper and nearest neighbor with the criteria of relatively numerous insignificant variables (Balancing test), smaller pseudo $\mathrm{R}^{2}$ value and large matched sample size. The Method of matching that fulfills all these criteria's was chosen as being the estimator of the data. Except the kernel bandwidth of (0.01), all the matching algorism fulfills all mentioned above (numerous insignificant variables, smaller pseudo $\mathrm{R}^{2}$ and large matched sample size). Therefore kernel bandwidth $(0.25)$ has been selected randomly. kernel matching method with propensity score closest to bandwidth $(0.25)$ resulted lower pseudo $R^{2}(0.1078)$ value, well balanced covariates and large matched sample size that were 65 treated and 80 untreated with a total of 145 sample households by discarding only 22 unmatched (off support) households' (Table 10).

Table 10 Performance of matching estimators for sample households

\begin{tabular}{|c|c|c|c|}
\hline \multirow{2}{*}{ Matching estimator } & \multicolumn{3}{|c|}{ Performance criteria } \\
\hline & Balancing Test* & Pseudo $\mathrm{R}^{2}$ & Matched sample size \\
\hline \multicolumn{4}{|l|}{ Kernel Matching } \\
\hline With 0.01 band width & 11 & 0.1078 & 129 \\
\hline With 0.1 band width & 11 & 0.1078 & 145 \\
\hline With 0.25 band width & 11 & 0.1078 & 145 \\
\hline With 0.5 band width & 11 & 0.1078 & 145 \\
\hline Radius Caliper Matching & 11 & 0.1078 & 145 \\
\hline With 0.01 band width & 11 & 0.1078 & 145 \\
\hline With 0.1 band width & 11 & 0.1078 & 145 \\
\hline With 0.25 band width & 11 & 0.1078 & 145 \\
\hline With 0.5 band width & 11 & 0.1078 & 145 \\
\hline \multicolumn{4}{|l|}{ Neighbor Matching } \\
\hline 1 Neighbor & 11 & 0.1078 & 145 \\
\hline 2 Neighbor & 11 & 0.1078 & 145 \\
\hline 3 Neighbor & 11 & 0.1078 & 145 \\
\hline 4 Neighbor & 11 & 0.1078 & 145 \\
\hline Sample HHs & Off Support & On support & Total \\
\hline Treated & 2 & 65 & 67 \\
\hline Controlled & 20 & 80 & 100 \\
\hline Total & 22 & 145 & 167 \\
\hline Prob > chi $2=0.0290$ & & & \\
\hline
\end{tabular}

Source: Survey data (2018)

*Indicates number of insignificance variables 


\subsubsection{Testing the balance of propensity score and covariates}

After choosing the best performing matching algorism band width of kernel matching method bandwidth band width (0.25), the next task is to check the balancing of propensity score and covariates. The T-test suggests that the differences in household characteristics between the treated and controlled groups are jointly insignificance both before and after matching. The main purpose of the estimation of propensity score is to balance the distribution of the relevant variables in both treated and controlled groups but not to obtain a precise prediction of selection into treatment. Table 11 showed that all covariates after matching including sex of household head becomes insignificance which indicates that the balance test was well balanced

Table 11 Balancing Test of Matched sample

\begin{tabular}{|c|c|c|c|c|c|c|c|c|}
\hline \multirow[t]{2}{*}{ Covariant } & \multicolumn{3}{|c|}{ Before Matching (167) } & \multicolumn{5}{|c|}{ After Matching(145) } \\
\hline & $\begin{array}{l}\text { Adopte } \\
\text { r (67) }\end{array}$ & $\begin{array}{l}\text { Non- } \\
\text { adopter } \\
(100)\end{array}$ & T-test & Adopter(65) & $\begin{array}{l}\text { Non- } \\
\text { adopter } \\
(80)\end{array}$ & Bias & $\begin{array}{c}\text { T- } \\
\text { Test }\end{array}$ & $\mathrm{P}>\mathrm{t}$ \\
\hline Sex & 1.11 & 1.10 & $1.73 *$ & 1.11 & 1.11 & 1.1 & 0.06 & 0.96 \\
\hline Age & 43.72 & 46.51 & -1.36 & 43.6 & 42.81 & 6.90 & 0.34 & 0.77 \\
\hline Farm experience & 21.42 & 22.78 & -0.74 & 21.28 & 20.10 & 11.1 & 0.61 & 0.54 \\
\hline Soybean Area & 1.34 & 1.23 & 0.8 & 1.34 & 1.34 & 0.1 & 0.00 & 0.99 \\
\hline Labor(ME) & 2.04 & 2.25 & -1.32 & 2.04 & 2.01 & 2.6 & 0.17 & 0.87 \\
\hline $\operatorname{Seed}(\mathrm{Kg} / \mathrm{ha})$ & 105.22 & 103.42 & 0.15 & 106.62 & 105.05 & 1.9 & 0.13 & 0.90 \\
\hline Seed(Kg/ha) & 105.22 & 103.42 & 0.15 & 106.62 & 105.05 & 1.9 & 0.13 & 0.90 \\
\hline Cost seed(kg/ha) & 770.63 & 785.10 & -0.14 & 781.88 & 783.69 & -0.3 & -0.02 & 0.99 \\
\hline Education & 2.84 & 2.79 & 0.08 & 2.82 & 3.12 & -9.7 & -0.52 & 0.60 \\
\hline Model farmer & 0.36 & 0.46 & -1.23 & 0.33 & 0.30 & 8.4 & 0.48 & 0.63 \\
\hline Mem Leader & 0.34 & 0.41 & -0.89 & 0.32 & 0.28 & 8.7 & 0.47 & 0.63 \\
\hline Access Finance & 0.36 & 0.28 & 0.92 & 0.35 & 0.31 & 8.7 & 0.51 & 0.61 \\
\hline $\begin{array}{l}\text { Train on } \\
\text { Soybean }\end{array}$ & 0.52 & 0.64 & -1.4 & 0.51 & 0.52 & -4.1 & -0.23 & 0.82 \\
\hline $\begin{array}{c}\text { Extension } \\
\text { Contact }\end{array}$ & 0.64 & 0.70 & -0.73 & 0.64 & 0.66 & -3.00 & -0.17 & 0.87 \\
\hline
\end{tabular}

Source: Survey data $(2018) * * *, * * *$ Indicates significance at 10,5 , and $1 \%$ respectively

\subsubsection{Treatment Effect on the treated (ATT)}

Average treatment effect(ATT) estimation using kernel matching method with bandwidth of (0.25), summarized the outcome variables of gross Farm income generated from soybean production as well as soybean productivity per hectare of the Adopter and Non-Adopters of improved soybean technology (Table 12 ). The result indicated that average treatment effect on the treated of gross farm income treated groups earns 9.14 equivalent to 25,401.66 ETB while the controlled were earned 8.72 equivalent to 20,172.58 ETB, indicating statistically significance between them. That is the average gross farm income of treated groups is greater than the average gross farm income of controlled groups earned from soybean production. The result shows the propensity of adoption decision of improved soybean has positive effect and statistically significance difference between adopters and nonadopters in terms of gross farm income earned from the soybean production. In general, the adoption decision of households for improving soybean variety has generated 5\% increasing in farm income of treated groups over controlled groups. Based on this result, adoption of improved technologies in this case improved soybean variety has positive effect, on increasing income of smallholder farmers from similar cultivated farm land in the study area. Over all the result is in line with finding of other researchers on the impact of soybean adoption by (Zemedu et al., 2017), Impact of high yielding wheat variety adoption (Dibaba and Goshu, 2018) and impact of food security package loan on food insecure households' income and asset creation by (Tesfay et al., 2018)

In addition to the income generate from the soybean production, this research tries to examine the productivity level of soybean between adopter and non-adopters. Adopter (treated groups/ were produced 2.90 equivalent to $20.98 \mathrm{qt} / \mathrm{ha}$ of soybean whereas the non-adopter were produced 2.51 equivalent to $16.64 \mathrm{qt} / \mathrm{ha}$, this indicated that average soybean productivity of treated groups is greater than the controlled groups. In general, the adoption decision of households for improving soybean variety has generated $15 \%$ increasing in soy bean productivity of treated groups over controlled groups. Based on this result, adoption of improved soybean varieties has positive effect, on increasing soybean productivity of smallholder farmers from similar cultivated farm land in the study area. Over all the result is in line with finding of other researchers on the determinants of improved teff varieties adoption and its impact on productivity(Afework et al., 2018) 
Table 12 Estimate of average treatment effects on Gross Farm Income of Household and Soybean productivity

\begin{tabular}{|c|c|c|c|c|c|c|}
\hline Outcome variable & Sample & Treated & Controls & Difference & $\mathrm{SE}$ & T-stat \\
\hline \multirow[t]{4}{*}{ Gross Farm Income } & Unmatched & $25,455.42$ & $21,402.43$ & 4052.98 & 2402.86 & 1.69 \\
\hline & ATT & $25,401.66$ & $20,172.58$ & 5229.08 & 2687.20 & $2.02 * *$ \\
\hline & ATU & $20,335.5$ & $26,352.83$ & 6017.33 & & \\
\hline & ATE & & & $5,663.98$ & & \\
\hline \multirow{4}{*}{$\begin{array}{l}\text { Log Gross Farm } \\
\text { Income }\end{array}$} & Unmatched & 9.15 & 8.85 & 0.30 & 0.10 & 2.36 \\
\hline & ATT & 9.14 & 8.72 & 0.42 & 0.11 & $3.18 * * *$ \\
\hline & ATU & 8.75 & 9.17 & 0.42 & & \\
\hline & ATE & & & 0.42 & & \\
\hline \multirow{4}{*}{$\begin{array}{l}\text { Soybean } \\
\text { Productivity }\end{array}$} & Unmatched & 21.15 & 17.89 & 3.26 & 1.97 & 1.65 \\
\hline & ATT & 20.98 & 16.64 & 4.35 & 2.12 & $2.05 * *$ \\
\hline & ATU & 16.78 & 21.98 & & & \\
\hline & ATE & & & 5.21 & & \\
\hline \multirow{4}{*}{$\begin{array}{l}\text { Log soybean } \\
\text { productivity }\end{array}$} & Unmatched & 2.91 & 2.63 & 0.28 & 0.12 & 2.63 \\
\hline & ATT & 2.90 & 2.51 & 0.39 & 0.13 & $3.45 * * *$ \\
\hline & ATU & 2.54 & 2.95 & 0.41 & & \\
\hline & ATE & & & 0.40 & & \\
\hline
\end{tabular}

Source: Survey data (2018)

$*, * *, * * *$ Indicates significance at 10,5 , and $1 \%$ respectively

\subsubsection{Sensitivity of the estimated average treatment effects (ATT)}

Matching algorism is done with the assumption of other exogenous variables does not exist and influence the ATT obtained due to adoption of improved soybean varieties. Based on this guidance sensitivity analysis is tested to check whether the unobserved covariates have effect on result obtained by creating bias. Sensitivity analysis is the final diagnostic that performed to check the sensitivity of the specification of the propensity score (Dehejia and Wahba, 2002). More ever, sensitivity analysis was undertaken to detect the identification of conditional independence assumption (CIA) and was satisfactory or affected by the confounder. The sensitivity test conducted in (Table 13) to check the ATT of farm income and soybean productivity was affected by confounder variables or not. According the test in (Table 13) ATT effect of farm income and soybean productivity due to adoption of improved soybean variety was not affected by confounders. The significance level is unaffected even if the gamma value are relaxed in any desirable level, shows that ATT is insensitivity to external change.

Table 13 Sensitivity analysis of the estimated ATT

\begin{tabular}{ccc} 
Gamma & Sigma $(\sigma+)$ & Sigma $(\sigma-)$ \\
1 & 0 & 0 \\
1.25 & 0 & 0 \\
1.5 & 0 & 0 \\
1.75 & 0 & 0 \\
2 & $1.1 \mathrm{e}-15$ & 0 \\
2.25 & $3.9 \mathrm{e}-14$ & 0 \\
2.5 & $6.8 \mathrm{e}-13$ & 0 \\
2.75 & $6.9 \mathrm{e}-012$ & 0 \\
3 & $4.9 \mathrm{e}-11$ & 0 \\
\hline
\end{tabular}

Source: Survey data $(2018)$

\section{Summaries and Conclusion}

The study was conducted at Metekel and Awi zone in North western Ethiopia, with the purpose of identifying the factors hinder and promote of improved soybean variety adoption and measures its impact on increasing income and productivity of smallholder soybean producers'. The result of logit regression revealed that adoption of improved soybean varieties was $40.36 \%$ which is moderate rate of adoption in the study area. it was also showed that member of any community leadership, social contact, main source of information about production and marketing, family size and distance to nearest market in minute was the main factors that determining improved soybean varieties adoption in the study area. The three former variables have statistically significance and positive effect whereas the latter two variables have statistically significance and negative effect on the adoption of improved soybean variety respectively.

The Propensity score matching (PSM) result showed that adopters of improved soybean variety were recorded higher impact over non-adopter in terms of productivity and gross farm income received. Adopters soybean productivity were $20.98 \mathrm{qt} / \mathrm{ha}$ whereas non-adopters were produced only $16.64 \mathrm{qt} / \mathrm{ha}$. The result showed that 
Adopters were received $4.35 \mathrm{qt} / \mathrm{ha}$ of soybean yield difference due to adoption of improved soybean variety. Moreover, Adopters of improved soybean variety were earned higher gross farm income than the non-adopters. Adopters were earned 25,401.66 ETB of gross farm income which is higher than the non-adopters were earned only 20,172.58 ETB of gross farm income which is lower than the adopters. The result indicated that Adopters were received 5,663.98 ETB of gross farm income difference over the non-adopters due to the adoption of improved soybean variety. The finding of this paper indicated that adopter of improved soybean variety has been brought $5 \%$ and $15 \%$ of increment in gross farm income and soybean productivity over the non-adopters as being adopter of improved soybean variety. In general, adoptions of improved agricultural technologies have ability to ensure food security of improved agricultural technology beneficiaries by increasing their productivity and incomes. Therefore, outreaching of improved agricultural varieties to all smallholder farmers should be given high priority to reduce poverty and ensure rural food security in Ethiopia.

Governmental and non-governmental organization(NGO) should be coordinating and conducting capacity building training to smallholder producers to actively participated in Member of any community leadership, training on agricultural technology production and marketing, social contact by conducting demonstration and experience sharing, to use recommend seed rate and supply improved seed at fair price. These factors have potential to increase the adoption rate of improved agricultural technologies as well as higher impacts on increasing of smallholders' agricultural productivity, increasing gross farm income, food security and poverty reductions.

\section{References}

Afework, H., Regasa, D., Chilot, Y., Endeshaw, H., 2018. Determinants of Improved Teff Varieties Adoption and Its Impact on Productivity: The Case of Non-Traditional Teff Growing Areas of Western Ethiopia. Journal of Natural Sciences Research Vol.8, No.22, 2018, 55-67.

ATA( Agricultural Transformation Agency), 2014. Transforming agriculture in Ethiopia. Annual report 2003/04.

Bekabil, U.T., 2015. Empirical review of production, productivity and marketability of soya bean in Ethiopia. International Journal of u-and e-Service, Science and Technology 8, 61-66.

Caliendo, M., Kopeinig, S., 2008. Some practical guidance for the implementation of propensity score matching. Journal of economic surveys 22, 31-72.

Cochran, W.G., 2007. Sampling techniques. John Wiley \& Sons.

CSA( Central Statistics Agency), 2018. Area and production of major crops Centeral Statistics, Government of Ethiopia.

Dehejia, R.H., Wahba, S., 2002. Propensity score-matching methods for nonexperimental causal studies. Review of Economics and statistics 84, 151-161.

Dibaba, R., Goshu, D., 2018. Impact Of High Yielding Wheat Varieties On Farm Income Of Smallholder Farmers In Ethiopia. Review of Agricultural and Applied Economics (RAAE) 21, 103.

Diro, S., Asfaw, E., Erko, B., Anteneh, M., 2017. Factors affecting adoption and degree of adoption of soya bean in Ilu-Ababora Zone; Southwestern Ethiopia. Agricultural Science Research Journal 7, 15-26.

FAOSTAT, 2015. Food and Agriculture Organization of the United Nations Statistical Database available athttp://www.fao.org/faostat.

Greenberg, P., Hartung, H.N., 1998. The Whole Soy Cookbook: 175 Delicious, Nutritious, Easy-to-prepare Recipes Featuring Tofu, Tempeh, and Various Forms of Nature's Healthiest Bean. Three Rivers Press (CA).

GTPII( Growth Transformation Plan II), 2015. Ministry of Agriculture and Rural Development Second Growth and Transformation plan. Addis Ababa, Ethiopia.

Gujarati, D.N., 2009. Basic econometrics. Tata McGraw-Hill Education.

Hagos, A., Bekele, A., 2018. Cost and returns of soybean production in Assosa Zone of Benishangul Gumuz Region of Ethiopia.

Hailu, M., Kelemu, K., 2014. Trends in Soy Bean Trade in Ethiopia. Research Journal of Agriculture and Environmental Management 3, 477-484.

JDAO( Jawi District Agrictulture Office), 2018. Annual Agricultural activities performance report.

Khandker, S.R., 2010. Micro-finance and Poverty. World Bank Publications.

Leuven, E., Sianesi, B., 2018. PSMATCH2: Stata module to perform full Mahalanobis and propensity score matching, common support graphing, and covariate imbalance testing.

Miruts, F., 2016. Analysis of the factors affecting adoption of soybean production technology in Pawe District, Metekele Zone of Benshangul Gumuz Regional State, Ethiopia. World Scientific News 53, 122-137.

PARC( Pawe Agriculture Research Center), 2018. Annual Report of Pawe Agricultural Research Center. Pawe,Ethiopia.

PDAO( Pawe District Agriculture Office), 2018. Annual Agricultural activities performance report.

Rosenbaum, P.R., Rubin, D.B., 1983. The central role of the propensity score in observational studies for causal effects. Biometrika 70, 41-55.

Smith, J.A., Todd, P.E., 2005. Does matching overcome LaLonde's critique of nonexperimental estimators? 
Journal of econometrics 125, 305-353.

Tesfay, W., Ayalew, Z., Aklilu, Z., 2018. Impact of Food Security Package Loan on Food Insecure Households' Income and Asset Creation: The Case of West Belesa District, North Gondar Zone, Ethiopia. Journal of Agriculture and Environmental Sciences 3, 87-110.

WorldBank, 2014. World Development Indicators

Zemedu, D., Bekele, D.A., Kedir, M., 2017. Adoption and Impact of Improved Soybean (Belessa-95) Variety among Smallholder Farmers in Bambasi Woreda, Benishangul Gumuz Regional State. Haramaya University. 